\title{
Factors Hindering Class Attendance: Views of University Accounting Students
}

\author{
Lillian Wally-Dima \\ Senior Lecturer, Faculty of Business, University of Botswana \\ E-mail: DIMALB@ub.ac.bw \\ Christian John Mbekomize (Corresponding author) \\ Senior Lecturer, Faculty of Business, University of Botswana \\ E-mail: mbekomizecj@ub.ac.bw
}

\author{
Alicia Nametsegang, \\ Lecturer, Faculty of Business, University of Botswana \\ E-mail: NAMETSEGANG@ub.ac.bw
}

Received: March 1, 2020 Accepted: May 7, $2020 \quad$ Published: June 1, 2020

doi:10.5296/ajfa.v12i1.16887 URL: https://doi.org/10.5296/ajfa.v12i1.16887

\begin{abstract}
This paper examines the factors that hinder university accounting students from attending classes. A survey instrument comprising of factors that impede class attendance was administered to the second, third and fourth year students doing accounting courses. Descriptive statistics were computed and Independent sample T-tests were performed to measure the variance in views among students from different years of study. The results suggest that studying for other tests, uploading of lecture materials to ICT platforms, failure to do the necessary reading in advance, working on the project which is due on the same day with a class, lack of proper time management and failure to properly allocate time to school activities are among the key factors responsible for absenteeism. Other hindrances to class attendance include having many lectures to attend in a day, transport problems to school, lack of personal motivation and time lag between classes. In addition, the results reveal that majority of respondents assess their class attendance to be satisfactory; and there is no evidence to indicate that course type, gender and accommodation status are among the causes of differences in class
\end{abstract}


attendance. These results have implications to students, lecturers, tertiary institutions and sponsors who can devise means to mitigate class absenteeism.

Keywords: accounting courses, class attendance, academic performance, year of study, university students 


\section{Introduction}

Class attendance at institutions of higher learning has been a topic for debate for a long time. It is reported that students at tertiary institutions do not attend classes on a regular basis. Various prior studies document a wide range of absenteeism rates. Romer (1993) reported the class non-attendance rate of 40\% and Friedman, Rodriguez and McComb (2001) documented that in some cases $25 \%$ or more students miss classes on a given day. Robert (2007) estimated that class non-attendance rates could reach to about $50 \%$ of students in some academic disciplines. Thatcher, Fridjhon and Cockcroft (2007) recorded a class absenteeism rate ranging from $35 \%$ to $60 \%$. These studies show that class non-attendance has been the problem that many tertiary institutions have been grappling with since many instructors associate class attendance with academic success while their students seem to be skeptical about that view (Credé, Roch, \& Kieszczynka, 2010). The University of Botswana where the current study is conducted is not an exception when it comes to absenteeism. The University wide study by Tidimane et al (2014) which investigated the failure rates and their causes at the University of Botswana identified class and tutorial attendance to be among the most important risk factors associated with failing a course. The University of Botswana is the largest university in a country with enrollment of about 14,000 students in 2019/2020.

Teaching and learning at the University of Botswana is predominantly face to face lecturing augmented by ICT platforms accommodating course materials which students can access anytime. Contact tutorials, group discussions and seminars are also conducted to support face to face teaching. Class attendance at higher education institutions in Botswana, of which the University of Botswana is part, is primarily non-mandatory. The approach has been to avoid infantilizing students and allowing them to make their own decisions whether to attend classes or not (Lukusa, Kaur, Kumari, \& Iyer, 2015). However, it appears this "academic freedom of attendance" might have caused students to skip classes on account of various reasons. At the University of Botswana class attendance is encouraged but absenteeism is not punished.

A decline in the number of students attending classes is a concern of higher learning institutions because non-class attendance is considered to be a significant contributor to poor academic performance. Numerous prior studies have confirmed a strong link between class attendance and academic achievement. Studies by Romer (1993) and Paisey and Paisey (2004) reported positive relationship between class attendance and academic performance. Chung (2004) documented that students who attend classes and/or tutorial on a regular basis are more likely to perform better academically than those who skip classes. LeBlanc (2005) found that class attendance significantly impacts tests scores for students from different sections and institutions. Ajiboye and Tella (2006) also reported a significant relationship between class attendance and academic performance among social studies students at the University of Botswana. Chen and Lin (2008) noted that class non-attendance is a problem that affects academic performance. Credé, Roch and Kieszczynka (2010) also established a strong relationship between attendance and class grades at State University of New York. Nyatanga and Mukorera (2017) and Papageorgiou (2019) reported a positive and significant relationship between lecture attendance and academic performance in South African Universities. 
Despite a myriad of studies supporting a strong link between class attendance and achievement, some studies argue academic performance cannot be pinned only on class attendance. Chung (2004) observes that some students attend classes regularly but do not achieve good results while others skip classes and succeed. Clair (1999) also opine that the association between class attendance and academic achievement should not be overemphasized since academic success is influenced by other factors such as students' feeling of being in control of learning environment. Caviglia-Harris (2004) investigated the relationship between class attendance and academic achievement using microenomics principles students in the USA and did not find attendance rates to be significant indicators of exam grades.

Although a good numbers of studies have been carried out worldwide to investigate the causes of classes' absenteeism among the undergraduates, very few researches have been conducted in Botswana to examine this phenomenon. This paper literature search revealed only two published studies conducted in Botswana about class attendance namely, Ajiboye and Tella (2006) at the University of Botswana and Lukusa, et al. (2015) at Botho University. The former focused on the impact of class attendance on academic achievement and established a significant association between the two while the latter examined the causes of absenteeism and truancy and identified delayed students allowances and time-tabling issues to be among the major causes of poor class attendance. This shows that there is still a knowledge gap regarding the factors causing high class absenteeism in higher learning institutions in Botswana and measures to combat it from students' perspective. The current study attempts to bridge this gap by seeking students' views regarding factors hindering class attendance and their opinions on which interventions can be implemented to reduce it, if not to eliminate it.

The findings of this study are expected to be beneficial to learners whose future livelihood, to larger extent, depends on their success at tertiary level. The results of this study will also be useful to higher education institutions, lecturers, parents, the government and professional accounting bodies all who are interested in the good performance of accounting students. A strong academic achievement of accounting students is crucial in Botswana since highfliers are expected to mitigate the prevailing acute shortage of citizen qualified chartered accountants in the country (Motsamai, 2018; Human Resource Development Council, 2016).

The subsequent sections review extant literature on the subject matter, highlight the methods employed to collect and analyze the data, describe and discuss the findings and present the conclusions and recommendations of the study.

\section{Literature Review}

\section{Problem of class non-attendance}

Various studies have attempted to assess the rate of class absenteeism. Robert (2007) estimated that class non-attendance rates could reach to about $50 \%$ in some academic disciplines. The study by Romer (1993) reported the class non-attendance rate of $40 \%$ in a biology course. Marburger (2001) examined the relationship between absenteeism and student' examination grades using principles of microenomics students and reports non-attendance rate of $18.5 \%$ in the course. Friedman, Rodriguez, and McComb (2001) in the United States reported the 
absenteeism rate of $25 \%$. In the work of Thatcher, Fridjhon and Cockcroft (2007) in South Africa the investigation of second year psychology class exhibited an average absenteeism rate of between $35 \%$ and $60 \%$. Despite the persistence of class absenteeism in many tertiary institutions globally some studies which have sought the views of students regarding the benefits of class attendance have indicate that most students prefer face to face learning as they find it beneficial in many ways such as enhancing their understanding of the course materials (Fung \& Carr, 2000; Schmulian \& Coetzee, 2011) and getting information about course procedures and tests cues (Friedman, Rodriguez, \& McComb, 2001).

\section{Effects of class non-attendance}

Numerous researchers have suggested that there is a positive correlation between class attendance and academic performance. The study by White (1992) found that students who miss class usually get lower grades. Devados and Folts (1996), Rodgers (2001) and Marburger (2001) concluded that class attendance is positively linked to academic performance. Paisey and Paisey (2004) who studied accounting students in Scotland reported that lecture attendance correlated positively with academic performance. LeBlanc (2005) carried out a study which examined the relationship between class attendance and average scores using the data from 4 institutions involving different courses over a period of 14 years and reported that class attendance significantly impacts tests scores for students from different sections and institutions. According to Ajiboye and Tella (2006) class attendance had a significant relationship with academic performance among social studies students at the University of Botswana. A similar study a few years later by Clark et al. (2011) using geography student at Lancaster University in the United Kingdom also came to the same conclusion that lecture attendance is positively related to academic performance. The study by Nyatanga and Mukorera (2017) in South Africa also confirmed a positive and statistically significant relationship between lecture attendance and academic performance among the first and second year students doing microeconomics and macroeconomics modules. Papageorgiou (2019) examined the first year accounting students in South Africa and documented a strong association between lecture attendance and academic performance.

Chen and Lin (2008) also reported that lecture attendance affects students' performance and they further reported that students who attended lectures were more likely to improve in their examination performance. According to Sleigh and Ritzer as cited by Schmulian and Coetzee (2011) students who do not attend lectures lose the benefit of learning from the questions asked by fellow students during class time and the explanation that the lecturer would have given. They further stated that students who skip classes also lose the opportunity to generate their own notes as an additional source of information beside the textbook. The work by Lukkarinena, Koivukangasa and Seppäläa (2016) in Finland revealed that a small cohort of students would succeed in exams without attending but for majority of students participation in teaching events is a significant explainer of academic achievement.

\section{Factors influencing class attendance}

Various factors are said to affect class attendance. Devadoss and Foltz (1996) and Paisey and Paisey (2004) reported that classes which were scheduled between 10am and 3pm had better 
attendance than those scheduled early or late in the day. Kotttasz (2005) reported that inconvenient lecture time is one of the reasons given by students for missing classes. Massingham and Herrington (2006) also found that time of class can affect class attendance. Lukusa et al. (2015) also reported that time tabling issues were among the significant contributors to class absenteeism.

Other factors that are thought to influence class attendance include engagement in part-time employment (McInnis \& Hartley, 2002; Massingham \& Herrington, 2006; Woodfield, Jessop $\&$ McMillan, 2006). Paisey and Paisey (2004) noted that in the accounting area, the most cited reason for non-attendance in classes was students' participation in part-time jobs. Westrick, Helms, McDonough and Breland (2009) found that students' illness is a major factor that contributes to non-attendance of classes.

Research carried out by Nasrulla and Khan (2015) found that the way in which students manage their time can have an effect on their academic performance and could also affect their daily routine and activities and personal achievements. Van Walbeek (2004) reported that gender also affects class attendance. On the contrary, Oldfield, Rodwell, Curry and Marks (2017), Lukusa et al (2015) and Kelly (2012) did not find gender to be a major restraining factor to class attendance.

Morgan (2001) in a study carried out at Bradford University in the United Kingdom stated that the most common reasons given by students for not attending classes were that students were out the previous night, having early classes and having backlogs of work to catch up on. Longhurst (1999), Paisey and Paisey (2004), and Westrick, et al (2009) also reported that engaging in various forms of social activities which can result in oversleeping affect class attendance.

Lack of interest in the subject was reported by participants in a study done by Paisey and Paisey (2004) in Scotland and Schmulian and Coetzee (2011) in South Africa. Both studies found that there was a positive relationship between class attendance and academic performance in accounting.

Earlier research such that of Devados and Foltz (1996) and Friedman et al. (2001) reported that lack of respect for the lecturer could also affect class attendance in a negative way. If students have little or no respect for the lecturer they might choose not to come to class which is conducted by that lecturer.

Schwartz (1997) investigated the influence that the internet has on student's performance. His findings were that the use of internet has led to a decrease in class attendance in some courses. Schwartz concluded that students who use the internet to access lecture information without attending classes were missing valuable interactive lecturer information. Similarly, GomisPorqueras, Meinecke and Rodrigues-Neto (2011) documented that the use of technologies which allow online access to class materials reduces class attendance. 
Interventions to improve Class attendance

As stated above the extant literature indicate that class attendance is influenced by a wide range of factors and therefore so are the interventions that are suggested to enhance class attendance. In the words of Clair (1999 p.179) "the classroom environment that engage students, emphasizes the importance of students' contribution, and have content directly related to knowledge assessed will undoubtedly provide encouragement to students to attend regularly". Similarly, Moores, Birdi and Higson (2019) reiterated the need of making the lectures interesting and interactive with a view of encouraging attendance. In the same vein, effectiveness of teachers and using real world settings in class (Fjortoft, 2005) and offering interesting course content (Van Schalkwyk, Menkveld and Ruiters, 2010) are said to incentivize students to attend classes. LeBlanc (2005) opined that attentiveness and immediacy of the lecture should be able to draw students to classes. Gump (2005) proposed that students should be given credit and bonus points for attending class. Early work done by White (1992) suggested rewarding attendance in order to enhance class attendance. Ssemugenyi, Mubaraka, and Nandacha (2013) advocated for extensive testing of material presented in class, administration of quizzes during class session and assigning more homework to foster class attendance. Counselling students on health issues and financial management matters were suggested by Lukusa et al (2015) as measures that can help to resolve some of the factors contributing to non-attendance.

\section{Methodology}

The target population for this study was students taking second, third and fourth level accounting courses of the 4 year Bachelor of Accountancy degree programme in the second semester at the University of Botswana. Three courses were randomly picked to provide the sample of the study. These were Introduction to Cost Accounting (ACC201) at the second level, Principles of Auditing (ACC309) at the third level and Financial Reporting (ACC410) at the fourth level. The registered number of students in these courses amounted to 841 but only 424 were targeted since only one group out of four groups of an average of 150 students taking ACC201 was targeted. It should be noted that the selected courses comprised students coming from other programmes than Bachelor of Accountancy.

Survey design was employed to collect the views of students using a self-administered questionnaire containing both closed and open ended questions. The questionnaire was in three sections. The first section collected the demographic characteristics of participants. The second section contained 32 statements about the factors that can hinder students from attending classes. Some of these items were adopted from studies by Jameel and Hamdan (2015) and Lang, Joyce, Conaty and Kelly (2008) but were modified to fit the current study environment. The responses to this set of statements were in 5-point likert scale with "strongly agree" on the high end and "strongly disagree" on the low end. The third section comprised two open-ended questions one of which asked students to suggest other factors that can hinder their class attendance while the other solicited students' views about how class attendance can be improved. 


\section{Macrothink}

Convenience sampling was used to select the respondents to the study as the questionnaires were administered during lecture time in classes after obtaining permission from lecturers responsible for targeted courses. Level 3 and 4 courses were offered by two researchers of this study. Permission was sought from one of the four lecturers co-teaching ACC201 to administer the questionnaire during class time. The purpose of the study was explained to students participating in the study and they were given 15 minutes to complete the questionnaire.

Descriptive statistics were computed and test of reliability to measure the internal consistency within the 32 items using Cronbach's alpha were performed. In addition, Independent samples T-tests were performed to measure how significant the differences in means between the responses of second years and third years, between third years and fourth years and between second years and fourth years were.

\section{Data Analysis and Discussion.}

\section{Demographic characteristics}

Out of 424 targeted students only 279 returned the questionnaires and all of them were found usable. Table 1 shows the demographic characteristics of the respondents with two-thirds of them being females and majority of them (95\%) being within 19 to 25 years of age group. Although only three courses were studied the students in these courses came from more than three programmes namely, Bachelor of Accountancy (36\%), Bachelor of Arts (Social Sciences) (15\%), Bachelor of Finance (14\%), Bachelor of Science (Computing and Finance) (16\%) and Bachelor of Business Administration (20\%). Of the three courses studied Principles of Auditing accounted for $47 \%$ of respondents while Financial Reporting and Introduction to Cost Accounting each contributed $28 \%$ and $25 \%$ respectively. Majority of respondents $(76 \%)$ were not accommodated in the university halls of residence and only a handful of them (24\%) resided in campus. 
Table 1. Demographic characteristics of respondents

\begin{tabular}{|l|l|l|}
\hline & Number & Percentage \\
\hline Gender & & \\
\hline Male & 95 & 34.1 \\
\hline Female & 184 & 65.9 \\
\hline Total & $\mathbf{2 7 9}$ & $\mathbf{1 0 0 . 0}$ \\
\hline Age group & & \\
\hline Under 19 years & 3 & 1.1 \\
\hline 19 to 25 years & 264 & 95.0 \\
\hline 26 to 30 years & 8 & 2.9 \\
\hline Above 35 years & 3 & 1.1 \\
\hline Total & 278 & 100 \\
\hline Programme & & \\
\hline BACC & 99 & 35.5 \\
\hline BASS & 42 & 15.1 \\
\hline BFIN & 39 & 14.0 \\
\hline Bsc & 44 & 15.8 \\
\hline Other & 55 & 19.7 \\
\hline Total & $\mathbf{2 7 9}$ & $\mathbf{1 0 0 . 0}$ \\
\hline Course Type & & \\
\hline ACC201 & 69 & 24.7 \\
\hline ACC309 & 131 & 47.0 \\
\hline ACC410 & 79 & 28.3 \\
\hline Total & $\mathbf{2 7 9}$ & $\mathbf{1 0 0 . 0}$ \\
\hline Accommodation Status & & \\
\hline Boarding & 66 & 23.7 \\
\hline Off campus & 213 & 76.3 \\
\hline Total & $\mathbf{2 7 9}$ & $\mathbf{1 0 0 . 0}$ \\
\hline & & \\
\hline & & \\
\hline
\end{tabular}

Class attendance and academic performance

Students were asked to self-assess their class attendance in general and their cumulative academic achievement from the beginning of their academic journey at the University until the last assessed semester. Table 2 reflects the students' class attendance and academic performance measured in Cumulative Grade Point Average out of 5. 
Table 2. Class attendance and academic performance

\begin{tabular}{|l|l|l|}
\hline & Number & Percentage \\
\hline Class attendance & & \\
\hline $\mathbf{0 \%}$ to 25\% & 10 & 3.6 \\
\hline $\mathbf{2 6 \%}$ to 50\% & 36 & 12.9 \\
\hline $\mathbf{5 1 \%}$ to 75\% & 82 & 29.5 \\
\hline Above 75\% & 150 & 54.0 \\
\hline Total & $\mathbf{2 7 8}$ & $\mathbf{1 0 0 . 0}$ \\
\hline Performance-CGPA & & \\
\hline Below 2.00 & 9 & 3.3 \\
\hline $\mathbf{2 . 0 0}$ to 2.99 & 71 & 26.1 \\
\hline $\mathbf{3 . 0 0}$ to 3.99 & 137 & 50.4 \\
\hline $\mathbf{4 . 0 0}$ to 4.69 & 48 & 17.6 \\
\hline $\mathbf{4 . 7 0}$ to 5.00 & 7 & 2.6 \\
\hline Total & $\mathbf{2 7 2}$ & $\mathbf{1 0 0}$ \\
\hline
\end{tabular}

Just above $50 \%$ of respondents assessed their class attendance to be above $75 \%$ and about $30 \%$ of them considered their class attendance to be between $51 \%$ and $75 \%$. Around $13 \%$ of respondents put their class attendance between $26 \%$ and $50 \%$ while $4 \%$ of them perceived their class attendance to be equal or below $25 \%$.

\section{Class attendance and demographic characteristics}

The cross tabulation analysis of class attendance per course as reflected in Table 3 revealed that $93 \%$ of students in second year course, and around $80 \%$ of students in both third and fourth year courses put their estimated class attendance above 50\%. However, while there was no single second year course student who estimated his/her class attendance to be below $25 \%$, just above $5 \%$ of students in the third year course and $4 \%$ of the fourth year course assessed their class attendance to be below $25 \%$. It is worth noting that the third year course, Principles of Auditing is essentially a non-mathematical course, while the second and fourth year courses, Introduction to Cost Accounting and Financial Reporting have a huge mathematical component. It has been argued that absenteeism is normally lower in courses with significant mathematical component (Romer, 1993; Schmulian \& Coetzee, 2011). It is therefore more likely that the non-mathematical nature of ACC 309 contributed to the higher rate of self-estimated non- class attendance. Other factors being held constant, these results tell us that students in second year have higher class attendance rate than their counterparts in third and fourth years. This is contrary to Jordaan (2009) who observed based on the evidence from prior studies that generally older students behave more responsibly towards lecture attendance. In addition, the earlier work by Chenneville and Jordan (2008) is also inconsistent with our results as they did not find a significant difference in attendance between lower and upper classes.

In this study the gender factor does not appear to be the cause of differences in class attendance rate since $84 \%$ of females and $82 \%$ of males estimated their class attendance to be above 50 . This is consistent with findings of Oldfield, Rodwell, Curry and Marks (2017) in the United 


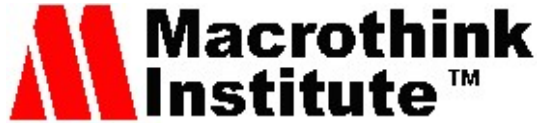

Asian Journal of Finance \& Accounting ISSN 1946-052X 2020, Vol. 12, No. 1

Kingdom; Lukusa et al. (2015) in Botswana; Kelly (2012) in Ireland; Chenneville and Jordan (2008) and Friedman, Rodriguez, and McComb (2001) in the United States who also did not find association between gender and attendance. Credé, Roch, \& Kieszczynka (2010) in the United States noted that gender affected attendance in a small way.

Table 3. Class attendance per course, gender, accommodation status and Cumulative GPA

\begin{tabular}{|c|c|c|c|c|c|}
\hline & $0 \%$ to $25 \%$ & $26 \%$ to $50 \%$ & $51 \%$ to $75 \%$ & Above 75\% & Total \\
\hline \multicolumn{6}{|l|}{ Course } \\
\hline ACC201 & $0.0 \%$ & $7.2 \%$ & $21.7 \%$ & $71.0 \%$ & $100.0 \%$ \\
\hline ACC309 & $5.4 \%$ & $15.4 \%$ & $30.0 \%$ & $49.2 \%$ & $100.0 \%$ \\
\hline ACC410 & $3.8 \%$ & $13.9 \%$ & $35.4 \%$ & $46.8 \%$ & $100.0 \%$ \\
\hline \multicolumn{6}{|l|}{ Gender } \\
\hline Male & $3.2 \%$ & $14.7 \%$ & $24.2 \%$ & $57.9 \%$ & $100.0 \%$ \\
\hline Female & $3.8 \%$ & $12.0 \%$ & $32.2 \%$ & $51.9 \%$ & $100.0 \%$ \\
\hline \multicolumn{6}{|c|}{$\begin{array}{l}\text { Accommodation } \\
\text { Status }\end{array}$} \\
\hline Boarding & $4.5 \%$ & $12.1 \%$ & $33.3 \%$ & $50.0 \%$ & $100.0 \%$ \\
\hline Off campus & $3.3 \%$ & $13.2 \%$ & $28.3 \%$ & $55.2 \%$ & $100.0 \%$ \\
\hline \multicolumn{6}{|l|}{$\begin{array}{l}\text { Cumulative } \\
\text { GPA }\end{array}$} \\
\hline Below 2.00 & $11.1 \%$ & $11.1 \%$ & $66.7 \%$ & $11.1 \%$ & $100.0 \%$ \\
\hline 2.00 to 2.99 & $2.9 \%$ & $11.4 \%$ & $35.7 \%$ & $50.0 \%$ & $100.0 \%$ \\
\hline 3.00 to 3.99 & $2.2 \%$ & $11.7 \%$ & $31.4 \%$ & $54.7 \%$ & $100.0 \%$ \\
\hline 4.00 to 4.69 & $6.3 \%$ & $20.8 \%$ & $12.5 \%$ & $60.4 \%$ & $100.0 \%$ \\
\hline 4.70 to 5.00 & $14.3 \%$ & $0.0 \%$ & $0.0 \%$ & $85.7 \%$ & $100.0 \%$ \\
\hline
\end{tabular}

Moreover, according to students who responded to this study's questionnaire accommodation status does not appear to be the reason for differences in class attendance patterns. An equal percentage $(83 \%)$ of boarding and of off-campus students estimated their class attendance to be above $50 \%$. This is contrary to our expectation as we anticipated off campus students to have relatively poorer class attendance than the students staying on campus since the former could be facing more inhibiting challenges than the latter. According to respondents Cumulative GPA appears to have an effect on class attendance. From Table 3 it is clear that the percentage of respondents who estimated their class attendance to be above $75 \%$ increased with the rise in Cumulative GPA. While only $11 \%$ of students with Cumulative GPA of below 2 assessed their attendance to be above $75 \%$ most of the students with Cumulative GPA of between 4.7 and $5(85 \%)$ estimated their class attendance to be above $75 \%$. This may imply that consistent failing may lead to disgruntlement and discouragement while good academic performance may spark students to put more effort into their school work. These results support the findings of numerous prior studies which reported positive association between lecture attendance and academic performance (Paisey \& Paisey, 2004; Clark et al., 2011; LeBlanc, 2005; Nyatanga and Mukorera, 2017; Papageorgiou, 2019). 
Factors influencing Class attendance

Regarding the internal consistency among the 32 question items measuring the causes of failure to attend classes, the reliability test revealed the Cronbach's alpha coefficient of 0.86 . This is an indication of strong internal consistency among the items affecting class attendance since the coefficient was above the lower limit of recommended score of 0.70 (Tavakol \& Dennick, 2011).

Table 4 shows the items statistics arranged in the descending order of mean scores starting with item which received the highest. Studying for other tests emerged as the strongest reason why students would fail to attend other classes (mean $=3.79$ ). This is consistent with Gump (2005) who reported that $66 \%$ of his respondents indicated that studying for another exam or working on another assignment was the reason for absenteeism. That means students would forgo classes in order to prepare for tests. This calls for the proper scheduling of continuous assessment items on part of the learning institution and academic staff during the semester. Lack of proper synchronization of tests and classes is more likely to disadvantage students as they may end up missing the valuable cues for the next tests for the class they missed. The second strongest reason for missing classes was the uploading of lecture materials to ICT platforms (Blackboard or Moodle) (mean =3.57). This means that if students knew that the entire course material will be uploaded to e-learning platforms they would not be motivated to attend classes. This is the conundrum that the learning institutions in general and lecturers in particular face as they strive to balance the support for the use of technology to facilitate independent study and encouraging face to face contact to enhance interactive learning through classroom questions and discussions. Gomis-Porqueras, Meinecke and Rodrigues-Neto (2011) call for extensive assessment of the net effect of use of technology on students' learning.

The third strongest factor to hinder class attendance according to sampled students is the failure to do the necessary reading in advance of the topic which is going to be discussed in the next class (mean $=3.09$ ). This finding is in contrast with Gump (2005) who found that only $8 \%$ of respondents agreed that unpreparedness for the class would prevent them from attending. At the same time the finding supports the argument by Gump (2005) that accepting attendance without preparedness would mean encouraging passive instead of active learning and it should only work where attending without preparation does not interfere with learning. But one would argue that failure to attend a class where the material which one has not read would be discussed puts a student in a lose-lose situation. The student fails to take advantage of discussions which will be held in class on the topic he/she has not prepared on. On the fourth place was the working on the assignment/project which is due on the day (mean=3.07). This finding also corroborates the results of Gump (2005) where $66 \%$ of respondents agreed that working on another assignment would interfere with their class attendance. This could be the result of genuine overload or students failing to properly schedule their work.

Lack of proper time management on part of students came fifth on the list of factors which would hinder appropriate class attendance $($ mean $=3.06)$. Failure to properly allocate time to school activities and having many lectures to attend in a day came sixth on the list of factors hampering class attendance each scoring a mean of 3.05. Transport problems to come to school 
were also among the top ten reasons why a student would fail to come to class (mean= 3.03). This finding is in agreement with observation by Davis, Hodgson and Macaulay (2012) that travelling time to school was one of the major factors discouraging class attendance at Monash University in Australia. This would mostly affect students who stay outside campus, who are in the majority at the University of Botswana. Lack of personal motivation (mean = 3.01) was also mentioned as one of the ten serious reasons why a student would not come to class. Several factors could be contributing to lack of personal motivation to come to class. Braak (2015) asserts that motivation can be both external and internal factor. According to the work by Braak (2015) $80 \%$ of hospitality students indicated that they attend class to listen and be exposed to theory while $20 \%$ of them were motivated to attend classes by other numerous factors.

The length of time between lectures was also identified to be among the ten most serious reasons why a student would miss a class (mean $=2.99)$. According to respondents, if a student has to wait for a long time before going to another lesson it would be a good reason for missing the next class. This is consistent with findings of Davis, Hodgson and Macaulay (2012) and Kelly (2012) who reported that large gaps between classes or few classes in a day negatively affect class attendance. In big institutions such as University of Botswana where the time table is centrally prepared and more often than not there are several courses to be allocated to limited class rooms long spacing between classes may seem unavoidable. Therefore this could be an area where new entrants into the University may need to be sensitized on to prepare them psychologically to face such challenges of tertiary education.

In contrast to conclusion of Davis, Hodgson and Macaulay (2012) that timetable clashes were the major factors influencing attendance, in this study timetabling clashes were the least factor to hamper attendance with mean score of 1.87 . This could be, perhaps, at the University of Botswana lecture clashes rarely take place and once identified and cannot be resolved the affected student is usually advised to deregister from the other course especially if that alternative is not going to affect the graduating date. The respondents of this study, surprisingly disagreed with the statement suggesting that the desire to emulate others who do not attend class (mean $=1.91$ ) would be the factor to deter them from attending class due. Although prior studies like that one by Westrick, et al. (2009) reported that students' illness would hinder class attendance, in the current study being genuinely sick (mean $=2.74)$ did not feature among the top ten causes of absenteeism. Overall, the average mean score of 2.62 as reflected in Table 4 indicates that students were not agreeable to most factors suggested to be hindrances to their class attendance. 
Table 4. Ranked factors hindering class attendance.

\begin{tabular}{|c|c|c|c|}
\hline \multicolumn{2}{|c|}{ Variables } & \multirow{2}{*}{\begin{tabular}{|l|} 
Mean \\
3.79 \\
\end{tabular}} & \multirow{2}{*}{$\begin{array}{l}\begin{array}{l}\text { Std } \\
\text { dev. }\end{array} \\
1.057 \\
\end{array}$} \\
\hline i. & I am studying for other test & & \\
\hline & $\begin{array}{l}\text { Contents of lecture include all information in Blackboard or } \\
\text { Moodle }\end{array}$ & 3.57 & 1.378 \\
\hline iii. & $\begin{array}{l}\text { I have not done the necessary reading in advance on the topic } \\
\text { of the course }\end{array}$ & 3.09 & 1.069 \\
\hline iv. & $\begin{array}{l}\text { I am working on assignment/project that is due on the same } \\
\text { day }\end{array}$ & 3.07 & 1.327 \\
\hline $\mathrm{v}$. & Lack of proper time management on my part. & 3.06 & 1.206 \\
\hline vi. & Failure to allocate time properly on my part & 3.05 & 1.254 \\
\hline vii. & Too many lectures to attend in a day & 3.05 & 1.292 \\
\hline viii. & $\begin{array}{l}\text { Transport problems to come to school (eg lack of tax/combi } \\
\text { fare, traffic jam, motor vehicle breakdown) }\end{array}$ & 3.03 & 1.54 \\
\hline ix. & Lack of personal motivation & 3.01 & 1.237 \\
\hline $\mathrm{x}$. & I have to wait for too long to go to the next class & 2.99 & 1.318 \\
\hline $\mathrm{xi}$. & Lack of interactive activities & 2.84 & 1.262 \\
\hline xii. & $\begin{array}{l}\text { The way the course is delivered does not appeal to my way of } \\
\text { learning. }\end{array}$ & 2.83 & 1.318 \\
\hline xiii. & Just being lazy (could not be bothered) & 2.80 & 1.287 \\
\hline xiv. & Genuinely sick & 2.74 & 1.334 \\
\hline $\mathrm{xV}$. & Unexciting/uninspiring lecturer & 2.72 & 1.317 \\
\hline xvi. & Large class size in terms of number of students & 2.66 & 1.16 \\
\hline xvii. & I can succeed in the course without going to lectures/tutorials & 2.65 & 1.222 \\
\hline xviii. & Distraction from other things such as movies and games & 2.64 & 1.193 \\
\hline xix. & $\begin{array}{l}\text { Family commitment, e.g. taking care of a sick relative, } \\
\text { attending bereavement }\end{array}$ & 2.59 & 1.304 \\
\hline $\mathrm{xx}$. & Instruction material of low quality & 2.43 & 1.146 \\
\hline xxi. & Class room not conducive & 2.33 & 1.155 \\
\hline xxii. & Being involved in part-time jobs & 2.24 & 1.257 \\
\hline xxiii. & I am unhappy with the lecturer(s) & 2.23 & 1.273 \\
\hline xxiv. & Class attendance is not the best use of my time & 2.17 & 1.034 \\
\hline $\mathrm{xxv}$. & $\begin{array}{l}\text { Being involved in extra curricula activities e.g member of } \\
\text { soccer team. }\end{array}$ & 2.14 & 1.137 \\
\hline xxvi. & $\begin{array}{l}\text { I am doing a course at the level lower than I am supposed to } \\
\text { be }\end{array}$ & 2.11 & 1.035 \\
\hline xxvii. & I am unhappy with the course(s) & 2.10 & 1.107 \\
\hline xxviii. & Time of the class too early in the morning & 2.05 & 1.227 \\
\hline xxix. & I am unhappy with classmates & 1.96 & 1.001 \\
\hline $\mathrm{xxx}$. & $\begin{array}{l}\text { Preferring following what is trending in social media rather } \\
\text { than attending classes }\end{array}$ & 1.96 & 1.017 \\
\hline
\end{tabular}




\section{Macrothink}

Asian Journal of Finance \& Accounting

ISSN 1946-052X 2020, Vol. 12, No. 1

\begin{tabular}{|c|l|l|}
\hline xxxi. $\quad$ Peer pressure- desire to be like others who do not attend & 1.91 & 1.071 \\
\hline xxxii. Clashing with another course & 1.87 & 1.049 \\
\hline AVERAGE & $\mathbf{2 . 6 2}$ & $\mathbf{1 . 2 1}$ \\
\hline
\end{tabular}

Comparison of means of second and third years' students

Table 5 shows the comparison of mean codes of the views of level 200 and level 300 courses on 32 factors that may hamper class attendance. Statistically significant differences in means of the views of students taking Introduction to Cost Accounting in the second year and those doing Principles of Auditing in the third year were observed in 10 out of 32 items at 5\% significance level. On the statement that a student can be successful in the course without going to lectures or tutorials, second year students had a mean of 2.43 while their counter parts in the third year had a mean of 2.82 with mean difference of -0.390 and $p$ value of 0.036 . Regarding whether being unhappy with a course can be the reason for not attending class, third year students had a mean of 2.3 while their counter parts in the second year had a mean code of 1.83 . The means difference was -0.488 and $p$ value was 0.004 . This means that third year students are more likely to miss the class because they are not amused with course. Put in other words, students taking Principles of Auditing are more likely not to come to class due to their hostile attitude towards the course than students taking Introduction to Cost Accounting. 
Table 5. ACC201 ( $\mathrm{N}=69)$ vs. ACC309 ( $=131)$ students' opinion about causes of poor class attendance

\begin{tabular}{|c|l|l|l|l|l|l|l|}
\hline \multicolumn{2}{|l|}{ ACC201 } & \multicolumn{2}{l}{ ACC309 } & \multicolumn{2}{l|}{ MD } & \multicolumn{2}{l|}{$\begin{array}{l}\text { t-test for equality of } \\
\text { means }\end{array}$} \\
\hline Variables & Mean & $\begin{array}{l}\text { Std } \\
\text { dev. }\end{array}$ & Mean & $\begin{array}{l}\text { Std } \\
\text { dev. }\end{array}$ & & t & Sig. \\
\hline i. $\quad \begin{array}{l}\text { I can succeed in the } \\
\text { course without going } \\
\text { to lectures/tutorials }\end{array}$ & 2.43 & 1.206 & 2.82 & 1.256 & -.390 & -2.114 & 0.036 \\
\hline ii. $\quad \begin{array}{l}\text { I am unhappy with the } \\
\text { course(s) }\end{array}$ & 1.81 & 1.061 & 2.3 & 1.172 & -.488 & -2.889 & 0.004 \\
\hline iii. $\quad \begin{array}{l}\text { I am unhappy with the } \\
\text { lecturer(s) }\end{array}$ & 1.80 & 1.106 & 2.30 & 1.287 & -.501 & -2.741 & 0.007 \\
\hline iv. $\quad \begin{array}{l}\text { I have to wait for too } \\
\text { long to go to the next } \\
\text { class }\end{array}$ & 2.35 & 1.082 & 3.28 & 1.377 & -.935 & -5.270 & 0.000 \\
\hline v. $\quad \begin{array}{l}\text { I am working on } \\
\text { assignment/project } \\
\text { that is due on the same } \\
\text { day }\end{array}$ & 2.64 & 1.372 & 3.15 & 1.344 & -.515 & -2.557 & 0.011 \\
\hline vi. $\quad \begin{array}{l}\text { I am studying for other } \\
\text { test }\end{array}$ & 3.59 & 1.142 & 3.96 & 0.956 &.- .368 & -2.286 & 0.024 \\
\hline $\begin{array}{l}\text { Too many lectures to } \\
\text { attend in a day }\end{array}$ & 2.80 & 1.170 & 3.35 & 1.347 & -.554 & -2.889 & 0.004 \\
\hline $\begin{array}{l}\text { The way the course is } \\
\text { delivered does not } \\
\text { appeal to my way of } \\
\text { learning. }\end{array}$ & 2.04 & 1.035 & 3.08 & 1.351 & -1.033 & -6.017 & 0.000 \\
\hline $\begin{array}{l}\text { Preferring following } \\
\text { what is trending in } \\
\text { social media rather } \\
\text { than attending classes }\end{array}$ & 2.12 & 1.182 & 1.76 & 0.921 & .360 & 2.203 & 0.030 \\
\hline $\begin{array}{l}\text { Unexciting/uninspiring } \\
\text { lecturer }\end{array}$ & 2.25 & 1.265 & 2.73 & 1.277 & -.479 & -2.528 & 0.012 \\
\hline viii. & & & & & & \\
\hline
\end{tabular}

Being unhappy with the lecturer was another factor where level 200 (means $=1.80$ ) and level 300 students (mean $=2.30$ ) had a significant difference in their views $(p=0.007)$. This means that level 300 students are more likely to miss lectures than the level 200 students on the grounds of being unhappy with the lecturer. The mean difference on this factor was -0.501 . The significant differences in mean scores $(p=0.000)$ between level 200 students and level 300 students was also identified on the statement about waiting for too long before getting into another class. The second year students reflected a mean code of 2.38 while the third year students reflected mean score of 3.28 resulting in a mean difference of -0.935 . This implies that 
the third year students are less resilient in relation to the duration they have to wait to catch the next class. A significant difference in views $(p=0.011)$ was also produced on the statement that working on an assignment which is due on the same day as the lecture would inhibit a student from going to class. Second year students had a mean code of 2.64 whilst their counterparts in the third year had a mean score of 3.15 with a mean difference of -0.515 . This implies that third year students were more agreeable to the statement than the second year. In addition, studying for another test was one of the factors that produced a significant difference in means $(p=0.024)$ between the second year (mean $=3.59)$ and third year students (mean = 3.96). Again the third years were more agreeable to the statement than the second years. Moreover, too many lectures to attend in a day produced a statistically significant difference $(p=0.004)$ in means of views of two cohorts. The second year students had a lower mean of 2.80 while their third year counterparts reflected a mean code of 3.35 with a mean difference of -0.554 .

Furthermore, the statement that the way the course is delivered does not appeal to student's way of learning yielded a significant difference in means $(p=0.000)$ among the second and third year students. The mean codes for second year and third year students on this factor were 2.04 and 3.08 respectively with the largest mean difference of -1.033 . Both second and third year students disagreed with the statement that they would prefer to follow what is trending in social media to attending classes. However, there was a statistically significant difference $(p=$ 0.030 ) in their views with second year students reflecting a mean score of 2.12 and third year students producing a lesser mean score of 1.76 . Another factor on which statistically significant difference in views $(p=0.012)$ between second and third year students was produced was the unexciting/uninspiring lecturer. On this factor second years had a mean code of 2.25 while the third years had a mean score of 2.73 implying that both groups disagreed with the statement that a boring lecturer would prevent them from attending class.

To sum up, Table 5 shows that 9 out of 10 factors in which the second and third years displayed significant differences in mean scores, third year students had a relatively higher mean scores than the second year students as exhibited by negative mean differences and t-values. These factors are: succeeding in a course without going to class, being unhappy with the course, being unhappy with lecturer(s) and waiting for too long before going to the next class. Other factors are working on other assignment, studying for tests, too many lectures in a day, the way the course is delivered not appealing to student's style of learning and unexciting lecturer. Second years' mean scores where higher than the third years' on only one statement suggesting that students would miss class on account of following up what is trending in social media. The average mean scores of each of the two cohorts are 2.47 for second years against 2.63 for third years. This implies that in general the mean scores of third year students were relatively higher than those of second year counterparts; meaning that the third year students were more agreeable with factors suggested as hindrances to attendance than the second year students. In fact, mean codes of the third years were superior to the second years in 20 items out of 32 . 


\section{Macrothink}

Comparison of means of second and fourth years' students

Table 6 shows the results of the t-test on views of the second year and fourth year students regarding the factors that hinder class attendance. Statistically significant differences in views of two groups were observed in only 9 items out of 32 at $5 \%$ significance level. Both second year's respondents doing Introduction to Cost Accounting and fourth year respondents taking Financial Reporting agreed that uploading lecture contents to ICT platforms hinder them from attending classes. There was a statistically significant difference in views of second year students $($ mean $=3.78)$ and of fourth year students $($ mean $=3.16)$ with a mean difference of 0.618 and $p$ value of 0.04 . There were also significantly divergent views $(p=0.000)$ regarding whether being unhappy with a lecture(s) would prevent the students from attending classes. Second year students reflected a mean of 1.80 while their counterparts in the fourth year produced a mean score of 2.51 implying that the latter is more likely to skip classes if they are not happy with lecturer(s). Waiting for too long to go to class was also the source of significant differences in views $(p=0.000)$ between the second year (mean $=2.35)$ and fourth year students (mean $=3.08)$. This factor seems to affect the fourth year students more than the second years. 
Table 6. ACC201 (N=69) vs. ACC410 (N=79) students' opinion about causes of poor class attendance

\begin{tabular}{|c|c|c|c|c|c|c|c|c|}
\hline \multirow{2}{*}{\multicolumn{2}{|c|}{ Variables }} & \multicolumn{2}{|c|}{ ACC201 } & \multicolumn{2}{|c|}{$\mathrm{ACC410}$} & \multirow[t]{2}{*}{ MD } & \multicolumn{2}{|c|}{$\begin{array}{l}\text { t-test for equality of } \\
\text { means }\end{array}$} \\
\hline & & \multirow{2}{*}{$\begin{array}{l}\text { Mean } \\
3.78\end{array}$} & \multirow{2}{*}{$\begin{array}{l}\begin{array}{l}\text { Std } \\
\text { dev. }\end{array} \\
1.247\end{array}$} & \multirow{2}{*}{$\begin{array}{l}\text { Mean } \\
3.16\end{array}$} & \multirow{2}{*}{$\begin{array}{l}\begin{array}{l}\text { Std } \\
\text { dev. }\end{array} \\
1.344\end{array}$} & & \multirow{2}{*}{$\begin{array}{l}\mathbf{t} \\
2.886\end{array}$} & \multirow{2}{*}{$\begin{array}{l}\text { Sig. } \\
.004\end{array}$} \\
\hline i. & $\begin{array}{l}\text { Contents of lecture } \\
\text { include all information } \\
\text { in Blackboard or } \\
\text { Moodle }\end{array}$ & & & & & .618 & & \\
\hline ii. & $\begin{array}{l}\text { I am unhappy with the } \\
\text { lecturer(s) }\end{array}$ & 1.80 & 1.106 & 2.51 & 1.309 & -.709 & -3.572 & .000 \\
\hline iii. & $\begin{array}{l}\text { I have to wait for too } \\
\text { long to go to the next } \\
\text { class }\end{array}$ & 2.35 & 1.082 & 3.08 & 1.217 & -.728 & -3.822 & .000 \\
\hline iv. & $\begin{array}{l}\text { I am working on } \\
\text { assignment/project } \\
\text { that is due on the same } \\
\text { day }\end{array}$ & 2.64 & 1.372 & 3.32 & 1.172 & -.679 & -3.247 & .001 \\
\hline $\mathrm{v}$. & $\begin{array}{l}\text { Large class size in } \\
\text { terms of number of } \\
\text { students }\end{array}$ & 2.93 & 1.264 & 2.42 & 1.008 & .510 & 2.687 & .008 \\
\hline vi. & Genuinely sick & 2.49 & 1.313 & 3.28 & 1.290 & -.786 & -3.665 & .000 \\
\hline vii. & $\begin{array}{l}\text { The way the course is } \\
\text { delivered does not } \\
\text { appeal to my way of } \\
\text { learning. }\end{array}$ & 2.04 & 1.035 & 3.13 & 1.213 & -1.083 & -5.861 & .000 \\
\hline viii. & $\begin{array}{l}\text { Instruction material of } \\
\text { low quality }\end{array}$ & 2.22 & 1.162 & 2.84 & 1.148 & -.618 & -3.249 & .001 \\
\hline & $\begin{array}{l}\text { Unexciting/uninspiring } \\
\text { lecturer }\end{array}$ & 2.25 & 1.265 & 3.15 & 1.312 & -.906 & -4.260 & .000 \\
\hline
\end{tabular}

Statistically significant difference in means $(p=0.001)$ was also witnessed with the statement about working on other assignment/project that is due on the same day. The fourth year students were more agreeable to the statement (means $=3.32$ ) than the second year students $($ mean $=2.64)$ with a mean difference of -0.679 . This could be due to the fact that as students move to the higher academic levels their workload intensifies. Large class size in terms of number of students also yielded a significant differences in views $(p=0.008)$ of second years and fourth year students. The second years registered a mean code of 2.93 whilst the fourth years registered mean scores of 2.42 with a mean difference of 0.510 . Interestingly being genuinely sick also yielded a significant difference in means between second year students $($ mean $=2.49)$ and fourth year students $($ mean $=3.28)$ with mean difference of -0.786 . These 
results were opposite to what was expected since under normal circumstances every student should be expected to miss a class on account of being genuinely sick.

The significant differences in views $(\mathrm{p}=0.000)$ were also detected in relation to the statement that the way the course is delivered is not in sync with student' way of learning. Fourth years were more agreeable to the statement (mean $=3.13)$ than second years (mean $=2.04)$ with mean difference of -1.083. Instructional material being of low quality was also the source of statistically differences in views $(\mathrm{p}=0.001)$ between second years $($ mean $=2.22)$ and fourth years $($ mean $=2.84)$. Second year students' views were statistically significant from those of fourth year $(p=0.000)$ regarding the factor of uninspiring lecturer. Fourth years respondents $($ mean $=3.15)$ were more agreeable to the factor being a hindrance to class attendance than the second year students $($ mean $=2.25)$.

In summary Table 6 shows that that in 7 items out of 9 fourth year students doing Financial Reporting reflected relatively higher mean scores than the second year students doing Introduction to Cost Accounting as shown by negative mean differences and t-values. Fourth years were more agreeable than the second years that being unhappy with lecturer(s), long waiting time before getting to another class, working on an assignment due on the same day of the lecture, large class size, ill-health, unpleasant delivery of the course, poor instructional material and unexciting lecturer would hinder them from going to class. The average of mean scores of each of the two groups are 2.47 for second years against 2.70 for fourth years implying that in general the mean scores of fourth year students were relatively higher than those of second year. Mean scores of the fourth years were superior to the second years in 26 items out of 32 .

\section{Comparison of means of third and fourth years' students}

Table 7 reflects the comparison of views of third year students doing Principles of Auditing and fourth year students taking Financial Reporting. Statistically significant differences in views between third year and fourth year students about the factors that can prevent students from attending class were detected in 9 items out of 32 items at 5\% significance level. Significant different views $(p=0.011)$ were expressed about the item regarding uploading lecture contents to ICT platforms. Third year students had a mean score of 3.68 whilst the fourth year students had 3.16 with a mean difference of 0.515 . This tells us that putting all lecture information to ICT platforms would affect more the class attendance of students taking Principles of Auditing than those doing Financial Reporting. Having many lectures to attend in a day was also a factor that reflected significant different means $(p=0.001)$ between third year student (mean $=3.35$ ) and fourth year students (mean $=2.73$ ) with mean difference of 0.617. Again we see here that class attendance of students taking Principles of Auditing will be more affected by number of classes to attend in a day than their counterparts doing Financial Reporting. Being genuinely sick also produced statistically significant different means ( $p=$ $0.000)$ between third year students (mean $=2.56)$ and fourth year student (mean = 3.28) with mean differences of -0.744 . The reason why this factor is producing significantly different views is not clear. Who would push himself or herself to come to class if genuinely sick? Preferring to follow what is trending in social media rather than attending class also created 
significant different views ( $p=0.003$ ) between students in third year (mean $=1.76$ ) and those in fourth years (mean $=2.15$ ) implying that third year students disagreed more with the statement than the fourth years.

Table 7. ACC309 ( $\mathrm{N}=131)$ vs. ACC410 (N=79) students' opinion about causes of poor class attendance

\begin{tabular}{|c|c|c|c|c|c|c|c|c|}
\hline \multirow{2}{*}{\multicolumn{2}{|c|}{\begin{tabular}{|l|} 
\\
Variables
\end{tabular}}} & \multicolumn{2}{|c|}{ ACC309 } & \multicolumn{2}{|c|}{ ACC410 } & \multirow{3}{*}{$\begin{array}{l}\text { MD } \\
.515\end{array}$} & \multicolumn{2}{|c|}{$\begin{array}{l}\text { t-test for equality of } \\
\text { means }\end{array}$} \\
\hline & & \multirow{2}{*}{$\begin{array}{l}\text { Mean } \\
3.68\end{array}$} & \multirow{2}{*}{$\begin{array}{l}\text { Std } \\
\text { dev. }\end{array}$} & \multirow{2}{*}{$\begin{array}{l}\text { Mean } \\
3.16\end{array}$} & \multirow{2}{*}{$\begin{array}{l}\text { Std } \\
\text { dev. }\end{array}$} & & \multirow{2}{*}{$\begin{array}{l}\mathbf{t} \\
2.576\end{array}$} & \multirow{2}{*}{$\begin{array}{l}\text { Sig. } \\
.011\end{array}$} \\
\hline i. & $\begin{array}{l}\text { Contents of lecture } \\
\text { include all information } \\
\text { in Blackboard or } \\
\text { Moodle }\end{array}$ & & & & & & & \\
\hline ii. & $\begin{array}{l}\text { Too many lectures to } \\
\text { attend in a day }\end{array}$ & 3.35 & 1.347 & 2.73 & 1.206 & .617 & 3.342 & .001 \\
\hline iii. & Genuinely sick & 2.56 & 1.290 & 3.28 & 1.290 & -.714 & -3.884 & .000 \\
\hline iv. & $\begin{array}{l}\text { Preferring following } \\
\text { what is trending in } \\
\text { social media rather } \\
\text { than attending classes }\end{array}$ & 1.76 & 0.921 & 2.15 & 0.962 & -.396 & -2.970 & .003 \\
\hline v. & $\begin{array}{l}\text { Being involved in } \\
\text { extra curricula } \\
\text { activities e.g member } \\
\text { of soccer team. }\end{array}$ & 2.02 & 1.126 & 2.37 & 1.146 & -.344 & -2.131 & .034 \\
\hline vi. & $\begin{array}{l}\text { Peer pressure- desire } \\
\text { to be like others who } \\
\text { do not attend }\end{array}$ & 1.73 & 0.959 & 2.19 & 1.188 & -.457 & -2.896 & .004 \\
\hline vii. & $\begin{array}{l}\text { Instruction material of } \\
\text { low quality }\end{array}$ & 2.28 & 1.083 & 2.84 & 1.148 & -.553 & -3.503 & .001 \\
\hline viii. & $\begin{array}{l}\text { Unexciting/uninspiring } \\
\text { lecturer }\end{array}$ & 2.73 & 1.277 & 3.15 & 1.312 & -.427 & -2.322 & .021 \\
\hline ix. & $\begin{array}{l}\text { Family commitment, } \\
\text { e.g. taking care of a } \\
\text { sick relative, attending } \\
\text { bereavement }\end{array}$ & 2.46 & 1.291 & 2.85 & 1.262 & -.390 & -2.140 & .034 \\
\hline
\end{tabular}

In addition, being involved in extra curricula activities also produced statistically significant different views $(p=0.034)$ from two groups of students. Third year students had a mean score of 2.02 while fourth year students had a mean code of 2.37 with a small mean difference of 0.344. Again the third year students perceived their class attendance being less affected by engaging in extracurricular activities than their counterparts in fourth year. Significant difference in views $(p=0.034)$ between third year students (mean $=1.73$ ) and fourth year (mean $=2.19)$ were also observed in relation to missing classes on the grounds of imitating 
others who do not attend classes. Although both groups negated the statement that suggested that they would miss a class in order to please those who usually don't attend classes, the third year students were less aggregable to the statement than the fourth year students.

Furthermore, low quality of instructional material as factor capable of causing class nonattendance produced a significant difference in mean scores $(p=0.001)$ between students doing Principles of auditing (mean $=2.28$ ) and their colleagues doing Financial Reporting (mean $=$ 2.84 ) with a mean difference of -0.553 . However, both classes disagreed with the notion that poor instructional material would prevent them from coming to class. Unexciting lecturer was also the cause of significant difference in means $(p=0.021)$ between third years and fourth years whereby the former registered a mean score of 2.73 while the latter recorded a mean score of 3.15 with a mean difference of -0.427 . A significant difference in views $(p=0.034)$ was also observed on the item about family commitment with third years showing a mean score of 2.46 and fourth years registering a mean code of 2.85 .

To cup up, Table 7 show that in 7 items out of 9 in which significant differences were spotted mean scores of fourth year students were relatively higher than those of their counterparts in the third year as indicated by negative mean differences and t-values. This means that fourth year students were more agreeable than the third year students that being genuinely sick, following what is trending in social media, involvement in extracurricular activities, desire to imitate those who do not come to class, poor quality of instructional material, unexciting lecturer and family commitment would prevent them from attending classes. The average means scores of 2.63 for the third years as opposed to 2.70 of fourth years indicate that in general the mean scores of the latter were relatively higher in most of the items than the former. In actual fact fourth years' mean scores were higher in 20 items out of 32 items.

Overall, the comparison of the mean scores of different years of study revealed that the higher class had relatively superior mean scores than the immediate lower class. This implies that the higher the students move in their programme the more excuses they would have for missing classes. While on one hand the reason for this finding could be associated with increased workload at the higher level, on the other hand it could be that students in higher classes get more familiar with the programme and college environment and become less serious with their studies.

\section{Other factors that affect class attendance}

Students were asked to suggest other factors contributing to poor attendance than those mentioned in the close ended questions. Classes scheduled late hours in the day was mentioned by students as the main reason for not coming to class followed by what was termed boring lecturer or non-motivating lecturer. Prior studies, for example, Paisey and Paisey (2004), Kotttasz (2005) and Massingham and Herrington (2006) mentioned late lecture time to be the major contributor to absenteeism. In addition, harsh weather and lack of funds to cover transport to and from school and food were also cited as factors hindering class attendance. Findings about insufficient funds for school requirements is consistent with findings of Lukusa et al. (2015) who reported that late allowances was among the top three factors contributing to absenteeism at Botho University. 
Regarding the question of how class attendance can be improved, respondents suggested the exciting and interactive classes as the prominent means to attract students to class. This supports the recommendations of Moores, Birdi and Higson (2019, p374) who assert that "academics wishing to encourage attendance should therefore seek to make their lectures interesting and interactive and try to create enjoyable social occasions". The other suggested approach to improve class attendance was moving classes to morning or mid-day hours from afternoon hours. These results collaborate the findings of Paisey and Paisey (2004) who documented that classes which are scheduled between 10 am and 3pm had better attendance than those scheduled early or late in the day. Moreover, participants were of the view that a combination of keeping attendance register and awarding marks for attendance would motivate students to attend classes. These suggestions imply making attendance mandatory and awarding it. Compulsory attendance in Botswana could be against the prevailing silent practice of allowing students to become adults by making their own class attendance choices. Some prior studies discourage mandatory attendance policies. Hyde and Flournoy (1986) reject mandatory class attendance because of the evidence that some students with poor attendance manage to attain outstanding academic achievement. Clair (1999) is against compulsory class attendance on the grounds that class attendance is more influenced by personal motivational beliefs and class context and therefore cohesive class attendance may deny students' control and make them feel bad about their decision to enroll with the higher education institution. Frisbie, Diamond and Ory (1979) and Clair (1999) refute the notion of awarding marks for attendance on the grounds that marks should only be a reflection of each student's competence in the course.

\section{Conclusion and Recommendation}

This study used the responses of self-administered survey from second, third and fourth year students of selected business core courses of Bachelor of Accountancy degrees at the University of Botswana to assess their self-estimated class attendance and their views on the factors that would influence class non-attendance. In general students perceived themselves to have a satisfactory class attendance as $54 \%$ of them assessed their normal class attendance to be above $75 \%$ and almost $84 \%$ perceived their class attendance to be over $50 \%$. Gender, type of course and accommodation status did not appear to be major sources of discrepancies in respondents' average class attendance. However, academic performance appeared to be a stimulus for class attendance.

Despite strong consistence among the items, only 9 items out of 32 had mean scores of above 3 out of 5 . In essence, students indicated that studying for other test, uploading course material to ICT platform, having not read in advance the topic(s) to be discussed in the class, being busy on other assignments and lack of proper time management would impede their class attendance. In addition, failure to allocate time properly, too many lectures/tutorials on the same day, transport problem and lack of personal motivation are among the 9 critical factors that would hamper class attendance in business programmes at the University of Botswana.

Moreover, this study revealed that on average students included in the sample negated most of the factors as being hindrances to their class attendance as indicated by average mean score 
ranging between 2.47 to 2.70 . In addition, the findings of this study suggest that the higher the year of study the more agreeable the students were to the factors affecting class attendance.

These results call for serious reflection by the three stakeholders on how to resolve the issues surrounding at least the top ten causes of class non-attendance. The university should find ways of sensitizing students about the importance of class attendance if they have to attain full benefits of their university enrollment. Academic staff should devise means of attracting students to classes. For example, for courses which have tests as components of their continuous assessment earmarking a week in which all tests could be administered would address the problem of missing classes due to tests. Awarding marks for class attendance can also entice students to come to class. Students need to develop a habit of having a continuous preparation for tests not to wait until the few days remaining to write to start reading. Having a good timetable which one can strictly adhere to will go a long way to address the issues of missing a class because of other tests or working on other assignments.

\section{Limitation of the study}

Only students that were in class when the questionnaire was being administered answered the questionnaire. Therefore the views of those that were absent and are probably the ones that do not attend classes on a regular basis were not captured. The views of the latter group are important in addressing the issue of class absenteeism. Administering the questionnaire in class might have caused the respondents to complete the questionnaire referring to the particular course they were attending at that time when completing the questionnaire instead of looking at their class attendance in general as it relates to other courses. Also the negative effect of self-assessment questionnaire as highlighted by Moores, Birdi and Higson (2019) and Demetriou, Ozer and Essau (2015) whereby respondents tend not to tell the whole truth might have constrained this study. The results of this study are limited to only students taking accounting courses at the exclusion of non-accounting students who might have different reasons from the targeted group. The views of students from other universities where also not examined. Also the study did not try to seek the opinion of instructors whose views could have reinforced or negated the views given by the students. Despite these limitations the study yielded important knowledge which is useful in addressing the class non-attendance by all interested stakeholders.

\section{Future Research}

Numerous factors are responsible for class absenteeism and therefore various studies may be done from different perspectives to understand the whole phenomenon. The study that compares the views about factors explaining class non-attendance from different learning institutions using both students and academic staff is highly recommended. Results of such a study have a high likelihood of attracting the attention of more stakeholders interested in enhancing learners' performance and therefore spark them to come up with effective measures. Notwithstanding the arguments against compulsory attendance and grading it in literature, respondents' views of implementing such need be respected. This paper therefore recommends for a university wide study to examine the views of a wider community of students on this 
subject. If it is found to be students' common view the university will have to find the ways of how to implement it while avoiding its negative consequences.

\section{References}

Ajiboye, J. O., \&Tella, A. (2006). Class attendance and gender effects on undergraduate students' achievement in a social studies course in Botswana. Essays in education, 18(1), 1.

Braak, D. (2015). An exploratory investigation into factors affecting class attendance in a hospitality management module.

Caviglia-Harris, J. L. (2004). Attendance Rates and Academic Achievement: Do Attendance Policies and Class Size Effects Impact Student Performance?. Available at SSRN 605462. https://doi.org/10.2139/ssrn.605462

Chenneville, T., \& Jordan, C. (2008). The impact of attendance polices on course attendance among college students. Journal of the Scholarship of Teaching and Learning, 29-35.

Chen, J., \& Lin, T. F. (2008). Class attendance and exam performance: A randomized experiment. The Journal of Economic Education, 39(3), 213-227. https://doi.org/10.3200/JECE.39.3.213-227

Chung, C. J. (2004). The impact of attendance, instructor contact, and homework completion on achievement in a developmental logic course. Research and Teaching in Developmental Education, 48-57.

Clack, G., Gill, N., Walker, M. \& Whittle R. (2011). Attendance and Performance: Correlation and Motives in Lecture Based Modules, Journal of Geography in Higher Education, 35(2) 199215. https://doi.org/10.1080/03098265.2010.524196

Clair, K. L. S. (1999). A case against compulsory class attendance policies in higher education. Innovative Higher Education, 23(3), 171-180. https://doi.org/10.1023/A:1022942400812

Davis, E. A., Hodgson, Y., \& Macaulay, J. O. (2012). Engagement of students with lectures in biochemistry and pharmacology. Biochemistry and Molecular Biology Education, 40(5), 300309. https://doi.org/10.1002/bmb.20627

Demetriou, C., Ozer, B. U., \&Essau, C. A. (2015). Self-Report Questionnaire. The encyclopedia of clinical psychology. https://doi.org/10.1002/9781118625392.wbecp507

Devados, S. \&Folts, J. (1996). Evaluation of factors influencing students class attendance and performance, American Agricultural Economics Association, 78, 499-507. https://doi.org/10.2307/1243268

Fjortoft, N. (2005). Students' motivations for class attendance. American Journal of Pharmaceutical Education, 69(1), 107-112.https://doi.org/10.5688/aj690115 
Friedman, P., Rodriguez, F., \&McComb, J. (2001). Why students do and do not attend classes:

Myths and realities. College teaching, 49(4), 124-133. https://doi.org/10.1080/87567555.2001.10844593

Frisbie, D. A., Diamond, N. A., \&Ory, J. C. (1979). Assigning course grades. Urbana, IL: Office of Instructional Resources, University of Illinois at Urbana, Champaign (ERIC Document Reproduction Service No. ED 285 496).

Fung, Y., \&Carr, R. (2000). Face-to-face tutorials in a distance learning system: meeting student needs. Open Learning: The Journal of Open, Distance and e-Learning, 15(1), 35-46. https://doi.org/10.1080/026805100115452

Gomis-Porqueras, P., Meinecke, J., \& Rodrigues-Neto, J. A. (2011). New technologies in higher education: Lower attendance and worse learning outcomes?. Agenda: a journal of policy analysis and reform, 69-83. https://doi.org/10.22459/AG.18.01.2011.07

Gump, S. E. (2005). The cost of cutting class: Attendance as a predictor of success. College Teaching, 53(1), 21-26. https://doi.org/10.3200/CTCH.53.1.21-26

Human Resource Development Council (2016). Top Occupations in High Demand. Retrieved from https://hrdc.org.bw/sites/default/files/Top\%20Occupations\%20Jan\%202017.pdf

Hyde, R. M., \& Flournoy, D. J. (1986). A case against mandatory lecture attendance. Journal of Medical Education, 61(3), 175-176. https://doi.org/10.1097/00001888-198603000-00005

Jameel S.H. \& Hamdan A. (2015). Effects of students attendance on accounting students' performance, International Journal of Business and Management Review, 3(5), 79-93.

Jordaan, Y. (2009). Influencing factors on lecture attendance at a tertiary institution. South African Journal of Higher Education, 23(1), 98-112. https://doi.org/10.4314/sajhe.v23i1.44805

Kelly, G. E. (2012). Lecture attendance rates at university and related factors. Journal of Further and Higher Education, 36(1), 17-40. https://doi.org/10.1080/0309877X.2011.596196

Kottasz, R. (2005). Reasons for student non-attendance at lectures and tutorials: an analysis. Investigations in university teaching and learning, 2(2), 5-16.

Lang, M., Joyce, A., Conaty, F., \& Kelly, B. (2008). An analysis of factors influencing the attendance of first year university students. In Proceedings of European First Year Experience Conference, Wolverhampton, UK, May7-9).

LeBlanc, P. H. (2005). The relationship between attendance and grades in the college classroom. Department of communication, University of Texas at San Antonia, 1-19.

Lin, T.F. \& Chen, J. (2006). Cumulative class attendance and exam performance, Applied Economic Letters, 13(14), 937- 942. https://doi.org/10.1080/13504850500425733 
Longhurst, R. J. (1999). Why aren't they here? Students absenteeism in a further education college, Journal of Further \& Higher Education, 23(1), 61-80. https://doi.org/10.1080/0309877990230106

Lukkarinen, A., Koivukangas, P., \&Seppälä, T. (2016). Relationship between class attendance and student performance. Procedia-Social and Behavioral Sciences, 228(16), 341-47. https://doi.org/10.1016/j.sbspro.2016.07.051

Lukusa, J., Kaur, R., Kumari, B., \&Iyer, S. S. (2015). Combating absenteeism and truancy through interventions: A case of higher education students at Botho University.

Marburger D.R. (2001), Absenteeism and undergraduate exam performance, Journal of Economic Education, 32(2) 99-109. https://doi.org/10.1080/00220480109595176

Credé, M., Roch, S. G., \&Kieszczynka, U. M. (2010). Class attendance in college: A metaanalytic review of the relationship of class attendance with grades and student characteristics. Review of Educational Research, 80(2), 272-295. https://doi.org/10.3102/0034654310362998

Massingham, P., \& Herrington, T. (2006). Does attendance matter? An examination of student attitudes, participation, performance and attendance. Journal of university teaching \& learning practice, $3(2), 3$.

McInnis, C., \& Hartley, R. (2002). The impact of full time study and paid work on the undergraduate experience in Australian Universities, Commonwealth Department of Education, Science and Training, ISBN 0642772703.

Moores, E., Birdi, G. K., \& Higson, H. E. (2019). Determinants of university students' attendance. Educational Research, 61(4), 371-387. https://doi.org/10.1080/00131881.2019.1660587

Moore, S., Armstrong, C., \& Pearson, J. (2008). Lecture absenteeism among students in higher education: A valuable route to understanding student motivation. Journal of Higher Education Policy and Management, 30(1), 15-24. https://doi.org/10.1080/13600800701457848

Motsamai, M. (2018 August 16). Botswana: Regulated Accountancy Leads to Good Credit Rating -Botswana Daily News. Retrieved from http://www.dailynews.gov.bw/newsdetails.php?nid=44728

Morgan. P. G., (2001). Why aren't they always there? An analysis of student's attendance at lectures, paper presented at the BEST Conference, Windermere, April 2001.

Nasrullah, S \& Khan, M. S. (2015). The impact of time management on the students' academic achievements, Journal of Literature, Language and Linguistics, Vol 11.

Nyatanga, P., \&Mukorera, S. (2019). Effects of lecture attendance, aptitude, individual heterogeneity and pedagogic intervention on student performance: A probability model approach. Innovations in Education and Teaching International, 56(2), 195-205. https://doi.org/10.1080/14703297.2017.1371626 


\section{Al Macrothink}

Asian Journal of Finance \& Accounting ISSN 1946-052X 2020, Vol. 12, No. 1

Oldfield, J., Rodwell, J., Curry, L., \& Marks, G. (2017). Psychological and demographic predictors of undergraduate non-attendance at university lectures and seminars. Journal of Further Higher Education, 42(4), 509-523. https://doi.org/10.1080/0309877X.2017.1301404.

Paisey, P.,\&Paisey, N. J.( 2004). Student attendance in an accounting module- reasons for nonattendance and the effect on academic performance at a Scottish University, Accounting Education, 13(1) 39-53. https://doi.org/10.1080/0963928042000310788

Papageorgiou, E. (2019). Lecture attendance versus academic performance and prior knowledge of accounting students: An exploratory study at a South African university. South African Journal of Higher Education, 33(1), 262-282. https://doi.org/10.20853/33-1-2695

Robert, L. L. (2007). Class attendance: Is it important. Center for Teaching Excellence, United States Military Academy.

Rodger, J. (2001). A panel-data study of the effect of students attendance on university performance. Australian Journal of Education, 45(3), 284-295. https://doi.org/10.1177/000494410104500306

Romer, D. (1993). Do students go to class? Should they? Journal of Economic Perspectives, 7(3), 167-174. https://doi.org/10.1257/jep.7.3.167

Schmulian, A., \& Coetzee, S. (2011). Class absenteeism: Reasons for non-attendance and the effect on academic performance, Accounting Research Journal, 178-194. https://doi.org/10.1108/10309611111163718

Schwartz, P. N. (1997). If you build it, would they come to class? Human Ecology Forum, 25(4), 2.

Ssemugenyi, F., Mubaraka, C., \& Nandacha, J. (2013). Effect of student - lecturer attendance on academic performance at Cavendish University Uganda, Global Institute of Research and Education, 2(3), 1-3.

Thatcher, A., Fridjhon, P., \&, Cockcroft, K., (2007). The relationship between lecture attendance and academic performance in an undergraduate. Psychology class, 37(3), 656-660. https://doi.org/10.1177/008124630703700316

Tidimane, C., Roy, H., Pansiri, B.M., \& Forcheh, N. (April 2014). A study to determine the failure rates and their causes at the University of Botswana, Gaborone, University of Botswana.

Van Schalkwyk, S.,Menkveld, H. \&Ruiters, J. (2010). What's the story with class attendance? First-year students: Statistics and perspectives. South African Journal of Higher Education, 24(4), 630-645.

Van Walbeek, C., (2004), Does lecture attendance matter? Some observations from a first year economics course at the University of Cape Town, South African Journal of Economics, 72(4), 861-883. https://doi.org/10.1111/j.1813-6982.2004.tb00137.x 
Westrick, S. C., Helms, K. L., McDonough, S. K., \& Breland, M. L. (2009). Factors influencing pharmacy students' attendance decisions in large lectures. American Journal of Pharmaceutical Education, 73(5). https://doi.org/10.5688/aj730583

White, F.C. (1992). Enhancing Class Attendance. NACTA Journal, 13-15. https://doi.org/10.1007/978-94-011-2868-1_2

Woodfield, R., Jessop, D., \& McMillan, L. (2006). Gender differences in undergraduate attendance rates. Studies in Higher Education, 31(1), 1-22. https://doi.org/10.1080/03075070500340127 